O. Mital,

PhD in Economics, Associate Professor of the Department of economics, business and natural science, Taurida National University

ORCID ID: 0000-0002-4101-3081

L. Ladonko, Doctor of Economic Sciences, Associate Professor of the Department of Public Administration and Administration, Kyiv National University of Trade and Economics ORCID ID: 0000-0001-5982-7684

\title{
PRIORITY DIRECTIONS OF ACTIVATION OF INVESTMENT ACTIVITY OF THE REGIONS OF UKRAINE
}

\author{
О. Г. Мітал, \\ к. е. н., доцент кафедри економіки, підприємництва та природничих наук, \\ Таврійський національний університет \\ А. С. Аадонько, \\ А. е. н., доцент кафедри публічного управління та адміністрування, \\ Київський національний торговельно-економічний університет
}

\section{ПРІОРИТЕТНІ НАПРЯМИ АКТИВІЗАЦІЇ ІНВЕСТИЦІЙНОЇ АІЯАЬНОСТІ РЕГІОНІВ УКРАЇНИ}

The article highlights the key aspects of the modern development of investment activity in the regions of Ukraine and identifies the actual challenges of intensifying investment activity. On the basis of statistics the peculiarities of investment activity in Ukraine are investigated; characteristics of regional development potential, distribution of capital investments by regions are given, analysis of sources of financing of investment activity is provided. In the process of analyzing motives of investment activities investors were finded market motives. Important motives were the cost of labor, the level of overcoming barriers to import. The study identified a number of objective factors that impede investment activity are particularly acute: the imperfection of instruments to unlock the internal potential of the regions, - insufficient institutional support for investment policy in the regions and on the ground (investment policy development is traditionally the prerogative of the central authorities), tools to unlock the internal potential of regions through regional strategies. The severity of the problem of activation of investment activity is complemented by equally important subjective factors (corruption, low level of infrastructure development, poor protection of property rights, lack of sufficient financial sources for investments, excessive involvement of local authorities in the activity of enterprises).

As a result, it is necessary to increase the level of competitiveness of regions by optimizing and diversifying the structure of the economy, ensuring the effective specialization of regions with priority use of their own resource potential.

It is necessary to achieve balanced development of territories, development of interregional cooperation, prevent deepening of socio-economic inequality by forming "growth points", activate local economic initiative and strengthen rural potential, ensure socio-economic unity and unification of regional human development.

It is necessary to apply new approaches to the formation and implementation of regional development policy, the creation of a unified system of strategic planning and forecasting of the development of the state and regions, optimization of the system of territorial organization of power.

У статті висвітлено кАючові аспекти сучасного розвитку інвестиційної діяльності в регіонах України та визначено актуальні виклики активізації інвестиційної діяльності. На основі Статистичних даних дослідЖено особливості інвестиційної активності в Україні; надано характеристику потенціалу регіонального розвитку, розподілу капітальних інвестицій за регіонами, надано аналіз джерел фінансування інвестиційної діяльності. У процесі аналізу мотивів інвестиційні діяльності основними мотивами називали ринкові. Вагомими мотивами були вартість робочої сили, рівень подолання бар'єрів при імпорті.

Уході,дослідження встановлено низку об'єктивних чинників, що перешкоджають інвестиційній діяльності особливо гостро постають такі: недосконалість інструментів розкриття внутрішнього потенціалу регіонів, недостатня інституційна підтримка інвестиційної політики в регіонах та на місцях (розвиток інвестиційної політики традиційно залишається прерогативою органів центрального рівня), недосконалість інструментів розкриття внутрішнього потенціалу регіонів за допомогою регіональних стратегій. Гострота проблеми з активі- 
зації інвестиційноїдіяльності доповнюеться і не менш важливими суб'єктивними факторами (корупція, низький рівень розвитку інфраструктури, слабкий захист прав вАасності, віАСУтність достатньої кількості фінансових АЖерел для інвестицій, надмірне втручання місцевих органів влади в Аіяльність підприємСтв).

У підсумкУ зазначено, що для активізації інвестиційної діяльності в регіонах необхідно передусім підвищити рівень конкурентоспроможності регіонів за рахунок оптимізації та диверсифікації структури економіки, забезпечення ефективної спеціалізації регіонів з пріоритетним використанням власного ресурсного потенціалу. Також Ауже важливо досяГти збалансованого розвитку територій, запобігти поглибленню соціально-економічної нерівності шяяхом формування "точок зростання", активізації місцевої економічної ініціативи та посилення сільського потенціалу, забезпечити соціально-економічнуєдність та рівномірність регіональНого АюдСЬКого розвИТКУ.

Key words: investment potential, investment, activation of investment activity, development of the region, investment activity, development of territories.

Ключові слова: інвестичійний потенчіал, інвестичї, активізачія інвестичійной діяльності, розвиток регіону, інвестичійна діяльність, розвиток територій.

\section{FORMULATION OF THE PROBLEM}

One of the main functions of the state in a market economy is to promote the economic development of the country. Forming development institutions that stimulate the introduction of the latest technologies and the implementation of innovative activities, the state creates the conditions for investment activity and economic development. The growing roles of the regions in the socioeconomic development of the country, the decentralization of economic management determine the increasing responsibility of state authorities for creating a favorable investment climate in the regions.

\section{ANALYSIS OF RESEARCH AND PROBLEM} STATEMENT

For theoretical basis of the article the author chose the results of topical studies of investment attractiveness of regions, as well as analytical materials of leading institutes, which explored the main directions of increasing investment activity and provided a comprehensive analysis of key factors that determine the investment attractiveness of regions.

The purpose of the article is to analyze the characteristics of the investment activity of the regions and to systematize the key obstacles to the investment activity.

\section{RESEARCH RESULTS}

The concept of investment climate is complex and complex and is considered at both macro and micro- economic levels. The macroeconomic level, which includes indicators of the political, economic and social environment for investment, is crucial for analyzing the investment attractiveness of regions. The microeconomic level manifests itself through the bilateral relations of the investor company and specific state bodies, suppliers, buyers, banks, as well as trade unions and labor collectives of the host region. Macro- and micro-levels of the investment climate are mainly perceived by investors as a whole, as, for example, any efforts by government bodies to create an attractive investment climate may be blocked by specific actors in the region. The investment climate of the region is the set of political, social and economic factors that the investor takes into account when making investment decisions. Most important among these factors are the economic parameters of the region that attracts investment. The list of specific indicators characterizing the investment climate depends on the form of investment, the investor himself, the term and conditions of investment. For international credit and financial institutions, a prerequisite for investing is basically a government guarantee. Private investors in their decisions are guided above all by the parameters of development of the credit-financial system of the recipient region (debt indicator, availability of bank lending, fulfillment of previous debt obligations, etc.). For persons making portfolio investments, the prerequisites are the availability of an appropriate investment environment (a developed stock market with elements of the servicing infrastructure) and the possibility of income repatriation. In addition to financial indicators, investors who make direct investments are also interested in the characteristics of the recipient's domestic market (market capacity, purchasing power, market access, market infrastructure), resource base, tax level, availability of benefits for investors, and trade policy. The study [ 1 p. 30$]$ shows the results of a survey of foreign investors regarding the motives for making investment decisions.

According to this questionnaire, the main motives were called marketing options. Significant motives were the cost of labor, the level of overcoming barriers to imports. There are various approaches to assessing the investment climate of the national economy, which vary depending on the objec- 
tives of the study, in terms of the number of indicators analyzed, their qualitative characteristics, and the choice of indicators.

Domestic scientists suggest assessing the investment climate in Ukraine on the basis of highlighting the resulting entrepreneurial risk, the components of which are: socio-political risk, domestic economic risk, foreign economic risk.

Based on our study, it is advisable to assess the investment climate of the regions according to a point system, the advantage of which is the possibility of quantitative comparison of the main characteristics of the investment climate and the allocation all components and is a criterion for the attractiveness of the region.

The most complete system for assessing the investment climate in the region was developed by Yu.V. Orlovskaya.

Let us analyze the current state of economic activity of the regions of Ukraine.

In January-December 2019, economic development in most regions was characterized by a positive trend in the areas of industrial, agricultural and construction production, as well as a slowdown in inflationary processes in the consumer market.

According to the results of 2019, the volume of industrial production in Ukraine remained at the level of the corresponding period of the previous year (in 2018 an increase of $2.4 \%$ was observed).

According to the results of 2019, the index of capital investments in Ukraine was $115.5 \%$ (the fall was $0.9 \%$ ), the fall in the volume of capital investments was observed in only 9 regions.

The main directions of investment direction are characterized by concentration of capital investments in the branches of manufacturing $(20.1 \%)$ and construction $(17.7 \%)$, and direct investments (equity) from other countries - in the branches of manufacturing $(27.1 \%)$, financial and insurance activities $(25.3 \%)$, wholesale and retail trade, repair of motor vehicles and motorcycles $(12.8 \%$ in total). Instead, there is a lack of capital investment in mining and quarrying $(11.3 \%)$ and agriculture, forestry and fisheries $(7.3 \%)$ and direct investment in construction $(2.8 \%)$, rural, forestry and fisheries $(1.3 \%)$, mining and quarrying $(3.1 \%)[4]$.

As can be seen from Table 4, the main source of financing for capital investments remains the own funds of enterprises and organizations, through which 73.3 percent of capital investments have been utilized in 2019.

The share of bank loans and other loans in the total investment amounted to 7.7 percent.

State and local budgets utilized 9.0 percent of capital investments. The share of foreign investors' money accounted for 0.8 percent of all capital investment, and the share of household funds for housing construction -6.6 percent. Other funding sources account for 2.6 percent.

Volume of development of capital investments of Ukrainian enterprises in

In 2019, they amount to UAH 584.4 billion, which is $2.3 \%$ more than the volume of capital investments for the corresponding period of 2018 .

The leading areas of economic activity in terms of capital investment development in 2019 remain: industry - 40.3\%, construction $-10.8 \%$, agriculture, forestry and fisheries $-10.1 \%$, information and telecommunications $-3.7 \%$, wholesale and retail trade; repair of motor vehicles and motorcycles - $7.9 \%$, transport, warehousing, postal and courier activities $-8.4 \%$, public administration and defense;
The investment climate of the region

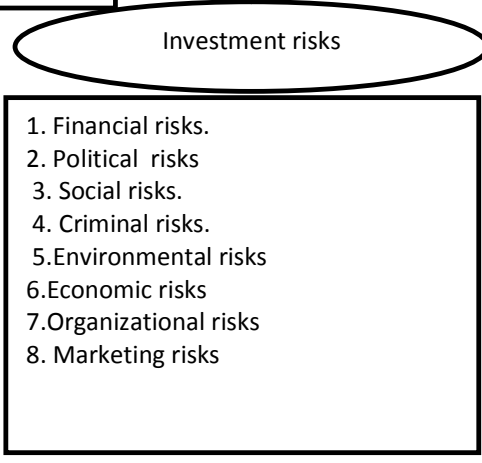

1. Financial risks

2. Political risks

ing investment attractiveness ya Yu.V. [2, p. 143]

Table 2. General economic development of the regions of Ukraine

\begin{tabular}{|l|l|l|}
\hline Region & $\begin{array}{c}\text { Indices of } \\
\text { industrial } \\
\text { production, } \\
\text { by region } \\
\text { for 2019 }\end{array}$ & $\begin{array}{c}\text { Agricultural } \\
\text { product } \\
\text { indices } \\
\text { by region } \\
\text { in 2019 }\end{array}$ \\
\hline Ukraine & $\mathbf{9 9 , 5}$ & $\mathbf{1 0 1 , 1}$ \\
\hline Vinnytsya & 114,7 & 102,1 \\
\hline Volyn & 94,9 & 100,2 \\
\hline Dnipropetrovsk & 101,0 & 107,2 \\
\hline Donetsk & 100,6 & 117,3 \\
\hline Zhytomyr & 94,3 & 100,3 \\
\hline Zakarpattya & 86,1 & 99,1 \\
\hline Zaporizhya & 95,5 & 123,2 \\
\hline Ivano-Frankivsk & 95,6 & 98,2 \\
\hline Kyiv & 99,7 & 94,2 \\
\hline Kirovohrad & 103,6 & 106,7 \\
\hline Luhansk & 96,0 & 110,7 \\
\hline Lviv & 97,0 & 100,7 \\
\hline Mikolayiv & 98,3 & 104,1 \\
\hline Odesa & 107,4 & 89,4 \\
\hline Poltava & 98,8 & 96,6 \\
\hline Rivne & 106,9 & 100,1 \\
\hline Sumy & 98,3 & 100,2 \\
\hline Ternopil & 98,3 & 98,1 \\
\hline Kharkiv & 96,7 & 101,6 \\
\hline Kherson & 104,4 & 102,8 \\
\hline Khmelnytskiy & 85,5 & 99,6 \\
\hline Cherkasy & 101,3 & 97,5 \\
\hline Chernivtsi & 100,3 & 98,1 \\
\hline Chernihiv & 89,9 & 97,5 \\
\hline City of Kyiv & 98,0 & - \\
\hline & & \\
\hline
\end{tabular}

Source: Ukrstat Annual Report [3].

compulsory social security $-5.4 \%$, real estate transactions $-4.9 \%[5]$.

Effective realization of the prospects of increasing the investment capacity of the regions of Ukraine is hampered by a number of factors:

- insufficient institutional support for investment policy in the regions and on the ground (investment policy development has traditionally remained the prerogative of central level authorities);

- imperfection of instruments for discovering the internal potential of regions through regional strategies (current regional development strategies provide an analysis of individual industries and spheres of activity that form the economic basis for a given region, but lack a systematic and comprehensive analysis of the internal potential of the region and determine how to use it);

- falling investment volumes as a result of worsening socio-economic situation in the country and falling investment attractiveness of the regions of Eastern Ukraine due to hostilities in their territories. 
Table 3. Distribution of capital investments

\begin{tabular}{|l|l|l|}
\hline \multicolumn{1}{|c|}{ Region } & $\begin{array}{c}\text { Capital } \\
\text { investment } \\
\text { indices, by } \\
\text { region, for } \\
\text { 2018 }\end{array}$ & $\begin{array}{c}\text { Capital } \\
\text { investment } \\
\text { indices, by } \\
\text { region, for } \\
\text { 2019 }\end{array}$ \\
\hline Ukraine & $\mathbf{1 1 6 , 4}$ & $\mathbf{1 1 5 , 5}$ \\
\hline Vinnytsya & 137,8 & 98,4 \\
\hline Volyn & 112,1 & 174,2 \\
\hline Dnipropetrovsk & 129,4 & 123,6 \\
\hline Donetsk & 154,6 & 124,7 \\
\hline Zhytomyr & 102,4 & 106,7 \\
\hline Zakarpattya & 117,3 & 126,4 \\
\hline Zaporizhya & 88,0 & 105,4 \\
\hline Ivano-Frankivsk & 84,7 & 102,0 \\
\hline Kyiv & 109,8 & 133,4 \\
\hline Kirovohrad & 91,0 & 122,8 \\
\hline Luhansk & 91,6 & 112,4 \\
\hline Lviv & 101,9 & 115,5 \\
\hline Mikolayiv & 87,4 & 140,1 \\
\hline Odesa & 95,9 & 98,3 \\
\hline Poltava & 105,5 & 139,7 \\
\hline Rivne & 108,7 & 94,6 \\
\hline Sumy & 108,5 & 106,7 \\
\hline Ternopil & 103,7 & 123,6 \\
\hline Kharkiv & 109,3 & 105,7 \\
\hline Kherson & 89,3 & 166,1 \\
\hline Khmelnytskiy & 96,5 & 94,2 \\
\hline Cherkasy & 132,4 & 104,0 \\
\hline Chernivtsi & 106,7 & 114,2 \\
\hline Chernihiv & 117,7 & 102,0 \\
\hline City of Kyiv & 130,6 & 109,0 \\
\hline & & \\
\hline & & \\
\hline
\end{tabular}

Source: Ukrstat Annual Report [3]

\section{CONCLUSIONS AND SUGGESTIONS}

The development of the regional economy and the reduction of territorial economic differentiation contributes to sustainable economic progress in the country. The main factor in the development of regional investment activity is the attractive investment climate in the region.

To activate investment activity in the regions, you need:

- increasing the level of competitiveness of regions by optimizing and diversifying the structure of the economy, ensuring effective specialization of regions with priority use of their own resource potential.

- achievement of a balanced development of territories, development of inter-regional cooperation, prevention of deepening of socio-economic disparities through formation of "growth points", activation of local economic initiative and strengthening of rural potential, ensuring of socio-economic unity and uniformity of regional development human development.

- application of common approaches to the formation and implementation of regional development policy, creation of a unified system of strategic planning and forecasting of the development of the state and regions, optimization of the system of territorial organization of power.

\section{$\Lambda$ ітература:}

1. Мурзина О.М. Экономическая сущность инвестиционной деятельности и ее государственного регулирования на региональном. Молодой ученый. 2011. № 10 . Т. 1. C. 133-137. URL https://moluch.ru/archive/33/3689/ (дата обращения: 10.03.2020).

2. Орловська Ю.В. Стратегічне управління інвестиціями в регіональний розвиток. - К.: Знання України, 2006. - 342 c.

3. Економічна статистика. Експрес-випуск 2019. URL: http://www.ukrstat.gov.ua/ (дата звернення 15.03.2020).

4. Капітальні інвестиції Експрес-випуск 2019 URL: http://www.ukrstat.gov.ua/operativ/operativ2019/ibd/ kin/arh_kin_u.htm (дата звернення 16.03.2020).
Table 4. Capital Investments by Financing Sources

\begin{tabular}{|c|c|c|c|c|}
\hline & \multicolumn{2}{|c|}{$\begin{array}{c}\text { Capital investment } \\
\text { utilized (used) in } 2018\end{array}$} & \multicolumn{2}{|c|}{$\begin{array}{l}\text { Capital investment } \\
\text { utilized (used) } \\
\text { in } 2019 \\
\end{array}$} \\
\hline & Mln.uan & $\begin{array}{l}\text { as a } \\
\text { percenta } \\
\text { ge of the } \\
\text { total }\end{array}$ & Mln.uan & $\begin{array}{c}\text { as a } \\
\text { percenta } \\
\text { ge of the } \\
\text { total }\end{array}$ \\
\hline Total & 526341,8 & 100,0 & \begin{tabular}{|l|}
584448,6 \\
\end{tabular} & 100,0 \\
\hline $\begin{array}{l}\text { including at the expense of } \\
\text { the budget }\end{array}$ & 21036,7 & 4,0 & 29536,7 & 5,0 \\
\hline $\begin{array}{l}\text { including at the expense of } \\
\text { local budgets }\end{array}$ & 45743,1 & 8,7 & 56047,5 & 9,6 \\
\hline $\begin{array}{l}\text { including at the expense of } \\
\text { the own funds of } \\
\text { enterprises and } \\
\text { organizations }\end{array}$ & 375309,1 & 71,3 & 397771,5 & 68,1 \\
\hline $\begin{array}{l}\text { including at the expense of } \\
\text { the bank loans and other } \\
\text { loans }\end{array}$ & 35299,8 & 6,7 & 40983,1 & 7,0 \\
\hline $\begin{array}{l}\text { including at the expense of } \\
\text { the funds of foreign } \\
\text { investors }\end{array}$ & 1540,2 & 0,3 & \begin{tabular}{|l|}
3541,4 \\
\end{tabular} & 0,6 \\
\hline $\begin{array}{l}\text { including at the expense of } \\
\text { the funds of domestic } \\
\text { investment companies, } \\
\text { funds, etc. }\end{array}$ & 4357,8 & 0,8 & 4817,7 & 0,8 \\
\hline $\begin{array}{l}\text { including at the expense of } \\
\text { the of housing funds }\end{array}$ & 33838,9 & 6,4 & 32666,4 & 5,6 \\
\hline other sources of funding & 9216,2 & 1,8 & 19084,3 & 3,3 \\
\hline
\end{tabular}

Source: Ukrstat Annual Report [3].

5. Статистична інформація. Стан інвестиційної діяльності в Україні. URL: https:// www.me.gov.ua/Documents/List?lang=uk-UA\&tag $=\% \mathrm{D} 0 \% \mathrm{~A} 1 \% \mathrm{D} 1 \% 82 \% \mathrm{D} 0 \%$ $\mathrm{B} 0 \% \mathrm{D} 0 \% \mathrm{BD} \% 20 \% \mathrm{D} 1 \% 96 \% \mathrm{D} 0 \% \mathrm{BD} \% \mathrm{D} 0 \% \mathrm{~B} 2 \%$ $\mathrm{D} 0 \% \mathrm{~B} 5 \% \mathrm{D} 1 \% 81 \% \mathrm{D} 1 \% 82 \% \mathrm{D} 0 \% \mathrm{~B} 8 \% \mathrm{D} 1 \% 86 \%-$ $\mathrm{D} 1 \% 96 \% \mathrm{D} 0 \% \mathrm{~B} 9 \% \mathrm{D} 0 \% \mathrm{~B}$ D \% D $0 \%-$ $\mathrm{B} \mathrm{E} \% \mathrm{D} 1 \% 97 \% 20 \% \mathrm{D} 0 \% \mathrm{~B} 4 \% \mathrm{D} 1 \% 96 \%-$ D $1 \% 8 \mathrm{~F} \% \mathrm{D} 0 \% \mathrm{BB} \% \mathrm{D} 1 \% 8 \mathrm{C} \% \mathrm{D} 0 \% \mathrm{BD} \% \mathrm{D} 0 \% \mathrm{BE} \%$ $\mathrm{D} 1 \% 81 \% \mathrm{D} 1 \% 82 \% \mathrm{D} 1 \% 96 \% 20 \% \mathrm{D} 0 \% \mathrm{~B} 2 \%$ $20 \% \mathrm{D} 0 \% \mathrm{~A} 3 \% \mathrm{D} 0 \% \mathrm{BA} \% \mathrm{D} 1 \% 80 \% \mathrm{D} 0 \% \mathrm{~B} 0 \% \mathrm{D} 1 \% 97 \% \mathrm{D} 0 \%-$ $\mathrm{BD} \% \mathrm{D1} \% 96$ (дата звернення 18.03.2020).

\section{References:}

1. Murzy`na, O. M. (2011), "Economic essence of investment activity and its state regulation at the regional level", Molodoj uchenyj, vol.10, no.1, pp. 133-137, available at: https:// moluch.ru/archive/33/3689/ (Accessed 10 March 2020).

2. Orlovs`ka, Yu.V. (2006), Strategichne upravlinnya investy"ciyamy` $v$ regional'ny'j rozvy tok [Strategic management of investments in regional development], Znannya Ukrayiny, Kyiv, Ukraine.

3. State Statistics Service of Ukraine (2020), "Economic statistics. Express release", available at: http:// www.ukrstat.gov.ua/ (Accessed 15 March 2020).

4. State Statistics Service of Ukraine (2019), "Capital Investments Express Issue", available at: http:// www.ukrstat.gov.ua/operativ/operativ2019/ibd/kin/ arh_kin_u.htm (Accessed 16 March 2020).

5. Ministry for Development of Economy, Trade and Agriculture of Ukraine (2020), "Statistical information. State of investment activity in Ukraine", available at: https://www.me.gov.ua/Documents/ List?lang $=$ uk-UA $\&$ tag $=\% \mathrm{D} 0 \% \mathrm{~A} 1 \% \mathrm{D} 1 \% 82 \% \mathrm{D} 0 \% \mathrm{~B} 0 \%$ $\mathrm{D} 0 \% \mathrm{BD} \% 20 \% \mathrm{D} 1 \% 96 \% \mathrm{D} 0 \% \mathrm{BD} \% \mathrm{D} 0 \% \mathrm{~B} 2 \% \mathrm{D} 0 \% \mathrm{~B} 5 \% \mathrm{D} 1 \%-$ $81 \% \mathrm{D} 1 \% 82 \% \mathrm{D} 0 \% \mathrm{~B} 8 \% \mathrm{D} 1 \% 86 \% \mathrm{D} 1 \% 96 \% \mathrm{D} 0 \% \mathrm{~B} 9 \% \mathrm{D} 0 \% \mathrm{~B}-$ $\mathrm{D} \% \mathrm{D} 0 \% \mathrm{~B} \mathrm{E} \% \mathrm{D} 1 \% 97 \% 20 \% \mathrm{D} 0 \% \mathrm{~B} 4 \% \mathrm{D}-$ $1 \% 96 \% \mathrm{D} 1 \% 8 \mathrm{~F} \% \mathrm{D} 0 \% \mathrm{BB} \% \mathrm{D} 1 \% 8 \mathrm{C} \% \mathrm{D} 0 \% \mathrm{BD} \% \mathrm{D} 0 \% \mathrm{BE} \%-$ $\mathrm{D} 1 \% 81 \% \mathrm{D} 1 \% 82 \% \mathrm{D} 1 \% 96 \% 20 \% \mathrm{D} 0 \% \mathrm{~B} 2 \% 20 \%$ D0\%A3\%D0\%BA\%D1\%80\%D0\%B0\%D1\%97\%D0\%BD\%D1\%96 (Accessed 18 March 2020).

Стаття надійшла до редакцї 25.03.2020 p. 